\title{
RUBÉN DARÍO Y SU HOMENAJE A PAUL VERLAINE
}

\author{
TEODOSIO FERNÁNDEZ \\ Universidad Autónoma de Madrid
}

\section{Resumen}

Al morir Paul Verlaine, a principios de 1896, Rubén Darío escribió el famoso "Responso" incluido después en su libro Prosas profanas y otros poemas. Con la intención de expresar sus deseos de paz para el cuerpo y el espíritu del admirado poeta fallecido, Darío elaboró una de sus creaciones más complejas, conjugando las referencias a la cultura grecolatina con las imágenes en las que él mismo había plasmado su visión de los escritores y artistas decadentes o malditos, los "raros" que por entonces ejercían sobre él una atracción irresistible y atormentada a la vez.

Palabras clave: Darío, Verlaine, Pan, Virgilio, Montaña de las Visiones.

\begin{abstract}
When Paul Verlaine died in the beginning of 1896, Rubén Darío wrote his famous "Responso" later included in his book Prosas profanas y otros poemas. Written with the intention of expressing his appreciation for the body and soul of the late and admired poet, Darío drafted one of his most complex pieces. In this work, he merges references to Graeco-Latin culture with images in which he had forged his visions of decadent and accursed writers and artists. The latter were those "weird" who, by then, were attracting him in irresistible and stormy ways.
\end{abstract}

Keywords: Darío, Verlaine, Pan, Virgil, Mountain of Visions.

Paul Verlaine murió en París, el 8 de enero de 1896. El 15 de ese mismo mes las páginas de Argentina (Duffau: 283), periódico que dirigía Alberto Ghiraldo, divulgaron en Buenos Aires los versos que Rubén había escrito en homenaje al poeta francés, y que terminaron incluidos en Prosas profanas y otros poemas, en la sección titulada «Verlaine», de nuevo dedicados a su amigo 
Ángel Estrada. Desde entonces son muchos los comentarios suscitados por ese poema, cuyo lenguaje se estimó alguna vez extravagante o incomprensible. Hoy parece innecesario aclarar que siringa es la flauta pastoril que Pan inventó y con la que interpretaba sus melodías, o que canéforas eran las doncellas que portaban las ofrendas en las fiestas religiosas de la antigua Grecia, o que linfa equivale a agua y es de uso común en la lengua poética de épocas muy diversas. Tampoco hay razones para volver sobre esas sextinas que combinaron alejandrinos y eneasílabos, para los que se encontró antecedentes en Victor Hugo y en alguna traducción del italiano (Marasso, 1954: 129). En los poemas del homenajeado también se ofrecen algunas soluciones similares, que Darío bien pudo aprovechar.

El «Responso» fue un resultado evidente de la admiración por Verlaine, especialmente acentuada en esos años que Rubén vivió en Buenos Aires. Fueron tiempos en los que con frecuencia buscó para su poesía la vaguedad de una expresión atenta sobre todo a la musicalidad que acentuase la capacidad de sugerencia, y los hallazgos del poeta francés le mostraban el camino. No sería difícil establecer la relación de ambos autores en otros aspectos, pero baste con la constancia de que fue estrecha, y de que justifica la actitud de Darío: Verlaine le había ayudado a encontrar un lenguaje adecuado a su concepción del poeta y de la poesía. Además, Rubén había hallado a alguien con quien identificarse, como cabe deducir de la semblanza que le dedicó en La Nación el 10 de enero de 1896 y que habría de incluir luego en el volumen Los raros. La había escrito también al conocer la noticia de su muerte ${ }^{1}$, y de sus referencias a la vida y la obra de Verlaine cabe deducir que cualquier detalle del «Responso» puede resultar significativo: si en la estrofa inicial se atribuye un alma «triste» al poeta francés, eso no solo supone la definición de un carácter, al menos si se tiene en cuenta que la semblanza lo situaba bajo «la maligna influencia de Saturno» (Darío, 1896: 25); como es sabido, esa influencia es la que padecen las personas de carácter sombrío, pero además hace referencia a Poèmes saturniens, el libro con que había iniciado su andadura literaria

1. No se refirió en ella al día de 1893 en que Alejandro Sawa lo llevó hasta el café D’Harcourt, en el parisino boulevard Saint Michel, y hasta el maestro admirado. Lo recordó o imaginó en 1912, al dictar su autobiografía (1912: s. p.): «Yo murmuré en mal francés toda la devoción que me fue posible, concluí con la palabra gloria... Quién sabe qué habría pasado esa tarde al desventurado maestro; el caso es que, volviéndose a mí, y sin cesar de golpear la mesa, me dijo en voz baja y pectoral: La gloire!... La gloire!... M...! M... encore!... Creí prudente retirarme, y esperar para verle de nuevo una ocasión más propicia. Esto no lo pude lograr nunca, porque las noches que volví a encontrarle, se hallaba más o menos en el mismo estado; y aquello, en verdad, era triste, doloroso, grotesco y trágico. Pobre Pauvre Lelian! Priez pour le pauvre Gaspard!...» 
en 1866. No en vano tal «Influence maligne» constaba en el verso final del poema que introducía el volumen (Verlaine, 1962: 57), poema del que Rubén había extraído también el epígrafe que abría el artículo publicado en La Nación. Esas referencias hablaban de la poesía y de los poetas, hijos de Saturno, nacidos bajo el signo de la melancolía.

La invocación que conforma la primera estrofa prefiere identificar al poeta muerto con otras figuras mitológicas. «¡Panida! Pan tú mismo» anima a deducir que Pan era el preferido, lo que la semblanza parece confirmar, al menos en la medida en que ese dios pastoril de la Arcadia se asocie en su condición de sátiro a ese "eterno prisionero del deseo» que Darío vio en Verlaine: «Al andar, hubiera podido buscarse en su huella lo hendido del pie. Se extraña uno no ver sobre su frente los dos cuernecillos, puesto que en sus ojos podían verse aún pasar las visiones de las blancas ninfas, y en sus labios, antiguos conocidos de la flauta, solía aparecer el rictus del egipán» (1896: 27). Esa identificación con Pan plantea, no obstante, algunos problemas, que esos mismos versos iniciales ponen de manifiesto: la invocación a Verlaine como portador de la lira remite a Orfeo, a quien Apolo regaló el «instrumento olímpico» con cuyo acento encantador había de dominar a los árboles y a las fieras. Sin duda Orfeo fue una figura fascinante para Darío: era la poesía y la música, y tenía el misterioso atractivo de haber viajado a los infiernos y de conocer de algún modo el mundo de los muertos. Por otra parte, el sistro y el tambor convierten en un tíaso o procesión báquica los coros que se dirigen al propíleo sacro, sugerente paganización de lo que en la semblanza fueron los discípulos de Verlaine, hijos de su espíritu, jóvenes oficiantes de la iglesia de aquel «lírico Sócrates de un tiempo imposible» (1896: 25). Las referencias mitológicas de esa estrofa inicial cubren así un espectro que abarca desde lo apolíneo hasta lo dionisíaco, dando a la significación poética de Verlaine una riqueza que Pan no podría agotar.

Verlaine había sido el instinto y la lujuria y a la vez la música y la armonía, según la evocación incluida en Los raros, pero no tratan de eso las cinco estrofas siguientes del «Responso», dedicadas a imaginar un escenario simbólico donde el cadáver del poeta pudiera descansar en paz. Aunque no falten razones para relacionar esas estrofas con la elegía pastoril «tradicional» (Trueblood, 1968), establecer con ella una dependencia estrecha equivale a descubrir enseguida que Darío no se atuvo estrictamente a modelo alguno. Puesto que se menciona a Virgilio, basta con la lectura de sus églogas ${ }^{2}$ para

2. Utilizo la edición que aparece en la bibliografía, pero entre paréntesis consignaré la égloga y el verso citados. Otro tanto haré con las referencias a Metamorfosis de Ovidio (libro y versos). 
comprobar que esa fuente literaria ofrecía lo necesario para imaginar la tumba de Verlaine en un paisaje bucólico, donde Pan cuida ovejas y a quienes cuidan ovejas. No en vano se alude a Títiro, que a la sombra del haya — «recubans sub tegmine fagi» (I, 1) — soplaba su caña y ensayaba sus cantos. La muerte también frecuentaba esos ámbitos, y al respecto merece mención especial la égloga quinta, donde Mopso comenta el fallecimiento de Dafnis, pastor que debía su nombre a haber nacido entre laureles, los que a su vez remiten a Dafne, la deseada por Apolo. El «simbólico laurel» del «Responso» revela así connotaciones profundas, aunque no necesariamente más que las venusinas flores de Citeres - las del mirto: «belle île aux myrtes verts, pleine de fleurs écloses», escribió Charles Baudelaire (con intención bien distinta) en «Un voyage à Cythère» (1991: 165)—, o que el pámpano verde que adornara las sienes de Baco o de Sileno, o que el acanto, que antes fue la ninfa Acante, también perseguida por Apolo. Como Darío no quería llanto sobre la tumba de Verlaine, expresó su deseo de que el paisaje imaginado y sus habitantes adoptaran la misma actitud. No ignoraba que tras la muerte de Dafnis el lobo no asedió a los rebaños, y ahora esperaba que el hocico de la fiera se humedeciese de amor, así como que el canto del ruiseñor ahuyentara los presagios funestos asociados al ave de mal agüero.

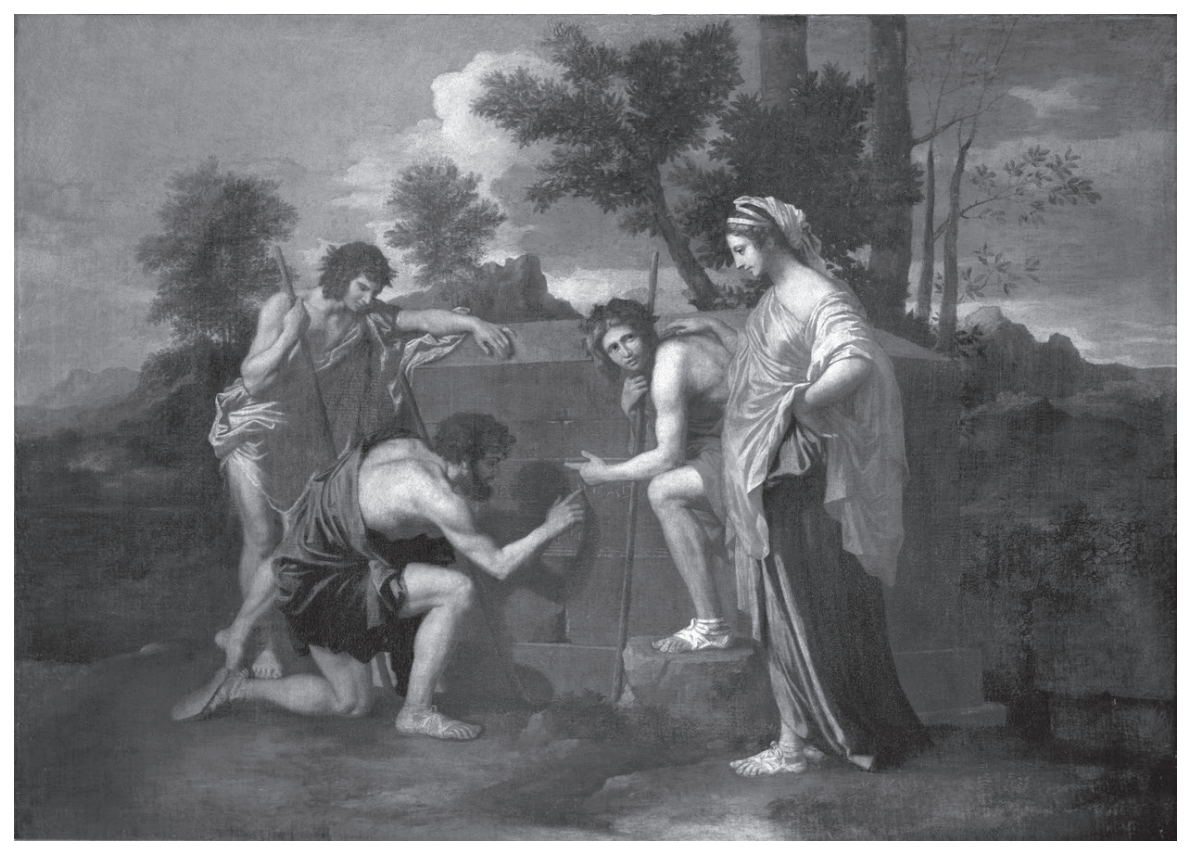

Nicolas Poussin: Et in Arcadia ego (Les bergers de l'Arcadie), 1838. 
Como la de Dafnis, la tumba de Verlaine debería convertirse en altar que recibiera las ofrendas con que otrora los pastores habrían de acercarse a los altares de Febo y del pastor fallecido «dumque thymo pascentur apes, dum rore cicadae» $(\mathrm{V}, 77)$ : mientras de tomillo se sustenten las abejas, y de rocío las cigarras. Habría de ser ese lugar de culto «oculto y florestal» donde en honor y gloria del muerto se reiterasen los cantos de los pastores y se imitasen los saltos de los sátiros. La leche fresca ya constaba allí entre las ofrendas previstas. Darío añadió la miel, pues no en vano era la de las abejas que solían aderezar la paz de los campos: como en su día las abejas hibleas, desde las flores de sauce que libaban en el cercado próximo, adormecían a Títiro - «saepe levi somnum suadebit inire susurro» $(\mathrm{I}, 55)$, diría Melibeo-, cabe imaginarlas arrullando el sueño eterno de Verlaine, ese sueño que ni siquiera el llanto por el difunto debería perturbar, como antaño tampoco lo hiciera el gemido de las tórtolas y de las torcaces. Las frescas mañanas primaverales del abril florido habrían de procurar el rocío, esa otra ofrenda de la naturaleza para ese altar en que se convierte la tumba del poeta. Ese paraje cultural imaginado por Darío no supone una exaltación de la vida sobre la muerte sino la concreción voluntariosa de una esperanza: la armonía de la naturaleza debe imponerse a cuanto pueda perturbar esa paz. No sin melancolía, pues en el silencioso paisaje arcádico, apenas alterado por el canto del ruiseñor y por rumores de caricias y besos, aún se anhela oír el nombre del poeta muerto en alguna canción que vuelva a despertar el miedo y la pasión de las náyades. Una náyade fue Syringa, aquella que en la Arcadia se arrojó al río Ladón, cuyas aguas la transformaron en las cañas con las que el enamorado y desdeñado Pan construyó su zampoña (Ovidio: I, 689-712).

Así llegamos a los versos con que Rubén expresa su deseo de que en la noche, en la negra montaña de las visiones, pase la gigante sombra extraña de un misterioso Sátiro espectral. Ese escenario y ese espectro no resultaban extraños para quienes habían leído «Frontispicio del libro de Los raros», texto que Rubén publicó en noviembre de 1895 en la Revue Illustrée du Río de la Plata. Ese texto mostraba al «dios-aparecido», el divino Pan antiguo, ahora del otro lado de la muerte:

Mirad sus brazos de momia, cómo sostienen los siete carrizos de Siringa; mirad su cabeza sin ojos, sus secas mandíbulas en donde algún resto de las barbas salvajes queda adherido, semejante a vegetación sepulcral; su boca que tanto supo de risa, de beso y mordisco sensuales, y que sopló tan soberanamente los más bellos cantos de la flauta, lanza hoy un aliento frío en el muerto instrumento, del cual brotan desconocidos sones, extrañas músicas de sueños, melodías de misterios profundos (1938: 79). 
Aunque resulte difícil precisar sus fuentes de información ${ }^{3}$, Darío sabía de la muerte de Pan y la aprovechaba para su «Frontiscipio», que en el contexto de Los raros debía adquirir su verdadera significación. De las semblanzas que pensaba reunir en ese libro futuro no eran pocas las que se ocupaban de poetas "decadentes": fue el caso de Jean Richepin, de cuyos versos brotó a veces «una demencia vertiginosa» (1896: 64); el de la perversa Rachilde, «satánica flor de decadencia, picantemente perfumada, misteriosa y hechicera y mala como un pecado» (1896: 91); el del belga Théodore Hannon, al que un Satán refinado hacía «rimar preciosidades infernales y cultivar sus flores de fiebre, esas flores luciferinas que tienen el atractivo de un aroma divino que diera la eterna muerte» (1896: 106); y sobre todo el del Conde de Lautréamont y sus Cantos de Maldoror, «un libro diabólico y extraño, burlón y aullante, cruel y penoso; un libro en el que se sienten a un mismo tiempo los gemidos del Dolor y los siniestros cascabeles de la Locura» (1896: 111). También el conde Matías Augusto de Villiers de l'Isle Adam, otro infeliz soñador, «aristócrata por sangre, arte y espíritu» que hubo de frecuentar «medios impropios de su delicadeza y realeza», y se resarció acercándose a veces a los territorios oscuros de la muerte y de lo sobrenatural (1896: 35-36). En función de Hannon, de Richepin, de Rachilde, de Lautréamont, de Villiers de l'Isle Adam, sin duda pensando en que ellos lo habitaban o lo habían visitado, Darío imaginó ese escenario simbólico:

La Montaña de las visiones, impregnada del aliento de la noche, alza sus torres de oscuros árboles poblados de espíritus errantes y sollozantes. Mirad, mirad en lo más negro de la montaña, y veréis brillar a veces ojos de fuego. La vasta y arcana montaña guarda sus hondos secretos, $y$ tan solo pueden saber las voces sin palabras de las visiones los que han oído, perdidos, ay, en la peregrinación, lo que brota de la boca sin labios de Pan espectral (1938: 79).

No es imposible que Darío recurriese a fuentes iconográficas para imaginar la montaña de las visiones y el Pan espectral ${ }^{4}$. Esa montaña no era sino la in-

3. Entre las posibles, prefiero la que proporciona Plutarco en el diálogo Por qué cesan los

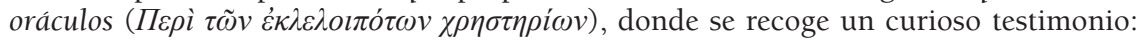
en tiempos del emperador romano Tiberio, alguien llamado Epiterses se dirigía hacia Italia cuando una tarde el navío en que viajaba fue llevado por las aguas desde las islas Equínadas hasta la de Paxos. Desde esta una voz fuerte llamó repetidamente al piloto egipcio Tamus, quien recibió el encargo de dar noticia de la muerte de Pan al llegar a las cercanías de Palodes. Así lo hizo, y apenas gritó hacia tierra «El gran Pan ha muerto», se elevó de inmediato un gemido múltiple y pleno de estupor (Def. orac. 419C).

4. Alfonso García Morales (1997) ya estudió la relación de la montaña de las visiones con la descripción del grabado Pan Mountain (1893) del pintor y escritor inglés Thomas Sturge Moore. 


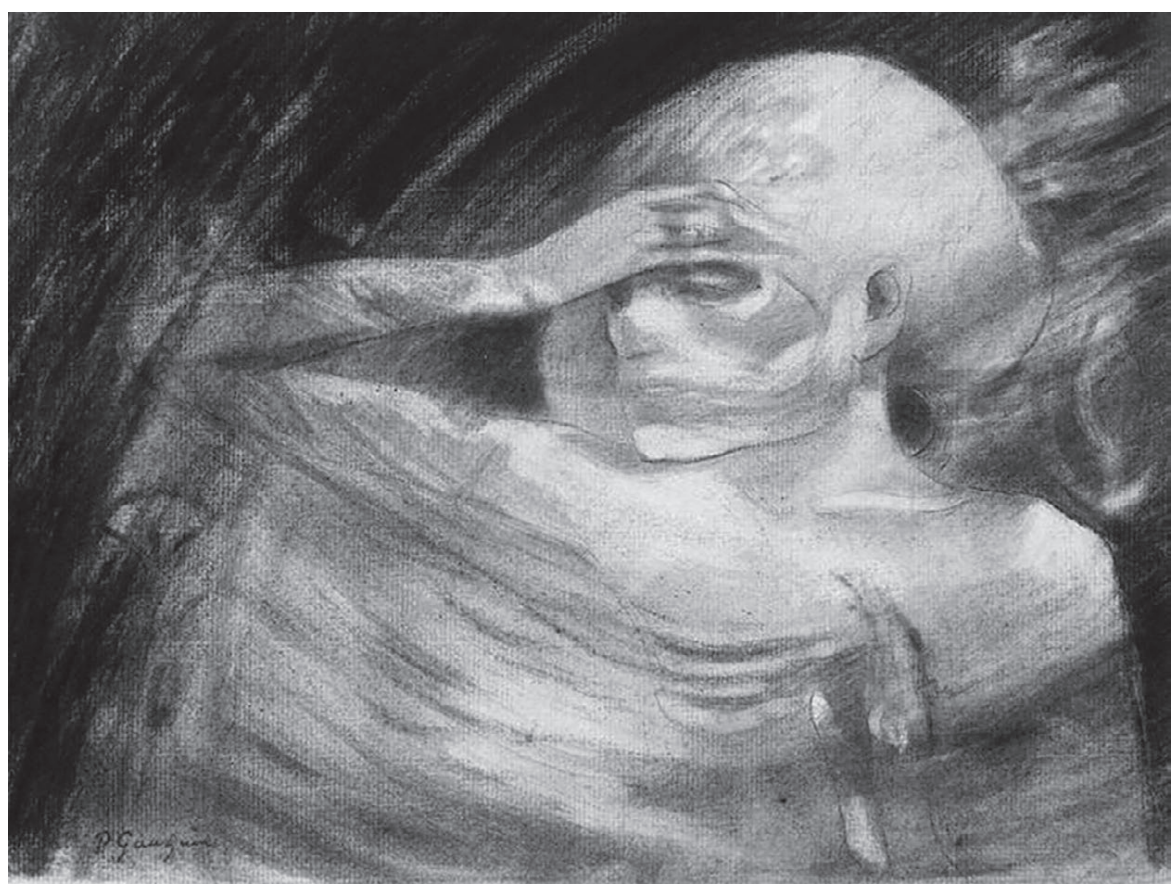

Paul Gauguin: Madame La Mort, 1891 [Dibujo para el libro Théatre d'Art de Rachilde, como ilustración de la pieza Madame La Mort, 1891].

quietante versión nocturna de la «montaña sonora» evocada para explicar en función de Pan y de Apolo la obra de Leconte de Lisle (1896: 9). En Los raros puede leerse una descripción del dibujo de Paul Gauguin que ilustró Madame la Mort, el drama simbolista de Rachilde, un espectro que emergía de un fondo de tinieblas y con el que el artista había evocado ciertas pesadillas en que «se contemplan cadáveres ambulantes, que se acercan a la víctima, la tocan, la estrechan, y en el horrible sueño se siente como si se apretase una carne de cera, y se respirase el conocido y espantoso olor de la cadaverina» (1896: 94). La condición visionaria de Gauguin resultaba acorde con la condición visionaria de Rachilde, y lo eran en su sentido más estricto: ambas remitían a un mundo de visiones o pesadillas que alguna vez afloraron en la poesía de Darío, como antes en «las sonrisas sin encías, / y las miradas sin ojos» del olvidado poema «Flores lívidas», o después, apenas insinuadas, en «la hora de los muertos» asociada al corazón de la noche en un «Nocturno» de Cantos de vida y esperanza. Sueños y visiones acosaban al endemoniado Lautréamont, arrastrándolo hasta los territorios del alcohol, de la locura y de la muerte, y no hay que ignorar al también visionario Edgar Allan Poe, «el cisne desdichado que 
mejor ha conocido el ensueño y la muerte», pues no en vano aquel soñador infeliz fue «el príncipe de los poetas malditos» (1896: 180). No es improbable que el recuerdo de «The Raven» — desplazando al de la corneja «sinistra» de Virgilio (IX, 15) - encontrara eco en el pájaro protervo que el dulce canto de Filomela debía alejar de la tumba de Verlaine.

Aunque el «Frontispicio del libro de Los raros» era anterior a su muerte, de la semblanza de Darío se desprende que Pauvre Lelian era otro de los destinados a habitar esa montaña siniestra: «Decíase que padecía de pesadillas espantosas y visiones en las cuales los recuerdos de la leyenda oscura y misteriosa de su vida, se complicaban con la tristeza y el terror alcohólicos» (1896: 26-27). Es difícil sustraerse a la tentación de ver en Los raros no solo la imagen de los autores comentados, en cuyas obras se conjugaban con tanta frecuencia el amor, el dolor y la muerte, sino también y sobre todo las experiencias e inquietudes de Rubén, enfrentado a los riesgos de una búsqueda literaria que en cualquier momento podía sobrepasar las fronteras de lo prohibido. Pero proyectar ese drama personal sobre el «Responso» equivale a apoyar su interés en los encantos de lo patético, sin que en verdad el poema necesite de ese atractivo adicional ni lo procure. Tal vez convenga limitarse a constatar que ahora el muerto era Verlaine, y que antes de que falleciera ya el espectral Pan habitaba o visitaba la montaña de las visiones. Darío no necesitaba ser más explícito al introducir en el poema ese escenario lúgubre y esa presencia extraña: eran conocidos para él y para cuantos había leído su «Frontispicio del libro de Los raros». Las músicas del dios-aparecido no eran precisamente tranquilizadoras, lo que justificaba el deseo de que ahora ajustara su melodía a la «harmonía universal».

Esa armonía invita a recordar que «Pan junta la soberbia de la montaña agreste / al ritmo de la inmensa mecánica celeste», según aseguraba Caumantes en «Coloquio de los centauros», y que años después Darío habría de referirse en el poema «Ama tu ritmo...» a la «celeste unidad», relacionándola con la divinidad o el alma del mundo para descubrirse así heredero, a su modo, del pitagorismo neoplatónico implícito en doctrinas románticas y simbolistas, que adivinaban un orden secreto bajo el mundo caótico de las apariencias. Por ahora solo manifestaba su deseo de que Pan ajustase sus melodías de ultratumba a la armonía general, asustando al adusto centauro y haciendo que el tropel equino huyera por la vasta montaña. Si este era el territorio inquietante de las pesadillas y visiones que habían atormentado a Verlaine, eran esas pesadillas y visiones las que ahora deberían desaparecer, permitiendo que la compasiva y blanca luz de la luna casta (podemos olvidar por esta vez la debilidad de Diana por Endimión) bañase el rostro de ultratumba del poeta 
francés, iluminando en alguna medida las tinieblas reinantes en ese territorio del otro lado de la muerte.

El resplandor definitivo llega con esa cruz que cubre el horizonte, irrupción sorprendente que cuenta ya con explicaciones razonables (Carlos, 1965). No hay de qué extrañarse, ni siquiera en relación con el poeta muerto, pues Rubén nunca había ocultado su intención de procurar a sus raros la vida eterna: puede advertirse su satisfacción al observar la evolución de Richepin, blasfemo cantor de la canalla, también marcado por la obsesión de la carne, quien con Mes paradis permitía augurar tiempos mejores: «Lo que hay de consolador y de divino en este poema es que al concluir presenciamos la apoteosis del Amor. Y el Amor lleva a Dios tanto o más que la Fe. Amor carnal, amor ideal, amor de las cosas, atracción, imán, beso, simpatía, rima, ritmo, el amor es la visión de Dios sobre la faz de la tierra» (1896: 69). Con esa intención recuperó citas de Léon Bloy que convertían a Lautréamont en un blasfemo por amor, y hasta en la perversa Rachilde supo descubrir un fondo de amor y de dulzura, de manera que ni siquiera en ese caso era inevitable la victoria de Satanás. Verlaine no podía ser una excepción, y más tras la lectura de Sagesse: en su semblanza lo veía "como un viviente, doble símbolo de la grandeza angélica y de la miseria humana» (1896: 27), y observó que «ese carnal pagano aumentaba su lujuria primitiva y natural a medida que se acrecía su concepción católica de la culpa» (1896: 27-28). Verlaine encarnaba así para Rubén el permanente conflicto entre las aspiraciones ideales del espíritu y las necesidades imperiosas de la carne, entre el arrepentimiento y las caídas. Ese conflicto era el que su poesía, «al eco de celestes o profanas músicas» (1896: 26), habría conseguido expresar.

En su Historia de mis libros, Darío recordó que en el «Responso» había tratado de mostrar «las dos faces» del alma «pánica» del homenajeado: «la que da a la carne y la que da al espíritu; la que da a las leyes de la humana naturaleza y la que da a Dios y a los misterios católicos, paralelamente» (1916: 29). El lector puede encontrar justificada esa explicación como referida a la semblanza publicada en La Nación - y también (en una dimensión esta vez autobiográfica) a un poema como «El reino interior», donde el mismo adverbio ya remitía a lo que los versos reunidos en Parallèlement habían significado: la dimensión infernal que el propio Verlaine oponía al poeta tocado por la gracia de Dios en Sagesse—, pero difícilmente extraerá del «Responso» conclusiones similares si no es ampliando con ayuda de aquella el significado de algunos indicios. Es lo que he hecho, incurriendo en el exceso muy frecuente de atribuir a un texto lo que no dice. Lo que consta en el ahora comentado es solo el deseo de que llegue la luz a la oscura montaña de las visiones y al 
espíritu torturado del poeta muerto. Tras el ámbito arcádico imaginado para la tumba, el espacio de ultratumba de las últimas estrofas completa el sentido de un poema que (simplemente) cabría resumir así: Paul Verlaine, has sido Apolo y Orfeo, Pan y Dionisos; que tu cuerpo y tu espíritu descansen (por fin) en paz. No hay que olvidarse del cuerpo torturado del poeta francés: Darío se refirió a su pierna «lamentable y anquilótica» y otros achaques que en sus últimos años, «en la hora de los implacables reumas y de las duras miserias parisienses» (1896: 25), lo habían hecho ver en los hospitales sus cuarteles de invierno. Sus huesos vagabundos habían encontrado el reposo, pero, en la hora final o tras ella, Rubén no podía desearle sino el descanso eterno, y ese descanso no se concebía ajeno a la cruz y a lo que esta significaba: «No era mala; estaba enferma su animula, blandula, vagula [sic]... ¡Dios la haya recogido en el cielo como en un hospital!» (1896: 30).

La muerte de Verlaine quizá significó para Darío un cambio de rumbo. La presencia de la cruz al final del «Responso» se ha interpretado como un triunfo del bien sobre el mal, de la fe católica sobre la estética paganizante (o de los remordimientos sobre las aficiones), y esa interpretación está justificada: Rubén sabía ya de las «bellas historias renovadas» en las que Anatole France recuperaba «viejas narraciones hagiográficas, en las cuales hay sátiros que adoran a Dios, y creen en su cielo y en sus santos, llegando en ocasiones hasta ser santos sátiros», leyendas que lo ayudaban a imaginar a ese Pauvre Lelian «mitad cornudo flautista de la selva, violador de hamadríades, mitad asceta del señor, eremita que, extático, canta sus salmos» (1896: 28). Cuando se ocupaba de Fra Domenico Cavalca, Darío se mostró convencido de que France había leído Vite dei Santi Padri «para escribir imitaciones tan preciosas como la "Leyenda" y "Celestin" de su Étui de nacre». Él, que conocía esas vidas ${ }^{5}$, sabía que un centauro señaló el camino a San Antonio cuando buscaba a San Pablo, primer ermitaño, y que un sátiro le ofreció dátiles y le rogó que

5. El capítulo de Los raros dedicado a su autor es la prueba mejor del interés que Vite dei Santi Padri mereció a Darío. Sus referencias se ajustan a lo narrado por Fra Domenico Cavalca, quien cuenta de «uno animale che parea mezzo uomo e mezzo cavallo (li quali li poeti chiamano Centauri)» cuya aparición dejó confuso a San Antonio, temeroso de que el demonio hubiera adoptado aquella forma monstruosa. El espanto se acentuó después al ver «quasi la forma d'un uomo piccolo col naso ritorto e lungo e con corna in fronte ed aveva i piedi quasi come di capra», el cual se apresuró a explicar que era una de esas creaturas mortales que los paganos «adorano per Dii e chiamano fauni, satiri e incubi», en nombre de los cuales pedía al santo que rogara por ellos «lo comune Signore», del cual sabían «essere venuto per la salute del mondo e in ogni contrada è sparta la sua fama» (Cavalca, 1830: 6-7). En cuanto a Anatole France, se refería sin duda a los relatos Amycus et Célestin y La Légende des saintes Oliverie et Liberette, incluidos en L'étui de nacre (1893). Un fauno y un ermitaño celebraban en el primero la Pascua de Resurrección, y 
intercediera «por él y sus compañeros con el nuevo Dios, con el triunfante Cristo» (1896: 157-158). Su Sátiro espectral observa la cruz, pero no huye de ella: solo huye el tropel equino, que esta vez parece representar esas miserias humanas que atormentaran al poeta.

La conciliación de paganismo y cristianismo habría de encontrar manifestaciones en la obra posterior de Darío, pero el «Responso» no exige mencionarlas. Sí conviene recordar (puesto que resulta imprescindible para la recta lectura del poema), que el «Frontispicio del libro de Los raros» no apareció en el volumen al que parecía destinado, y no solo porque en su conjunto las semblanzas reunidas dejaran a los decadentes finalmente en minoría. Allí se podía encontrar al «caminante joven» (1938: 80) que, con la alforja y la lira y sordo a las advertencias del poeta, se dirige hacia la negra montaña de los enigmas vislumbrados y de los misterios entrevistos ${ }^{6}$. «No sería prudente a los espíritus jóvenes conversar mucho con este hombre espectral», escribía Darío a propósito de Lautréamont, y añadía poco después: «Si yo llevase a mi musa cerca del lugar en donde el loco está enjaulado vociferando al viento, le taparía los oídos» (1896: 111-112). Frente a la montaña de las visiones, había imaginado ya una Colina Sagrada coronada por el templo de la Dea, de la eterna belleza, «en cuyo gesto está visible la música del universo», según declaró el 15 de octubre de aquel año 1896 en el Ateneo de Córdoba, en la sesión que Carlos Romagosa y otros entusiastas organizaron en su homenaje. «Ella y la fe llenan de luz el mundo», aseguró entonces (1970: 110), como si el arte significara no solo un refugio frente a las miserias del presente histórico, sino también una posibilidad de evitar la atracción de los abismos.

En la localidad cordobesa de Capilla del Monte, el 3 de ese mes de octubre, había firmado ya el prólogo que sirvió de introducción definitiva al volumen de sus raros, recuperando para la ocasión los ideales que el 19 de agosto de 1894, en el primer número de la efímera Revista de América, habían manifestado el propósito de hacer de aquella publicación el órgano de expresión de la juventud de América Latina que peregrinaba «a los Santos Lugares del Arte y a los desconocidos Orientes del Ensueño» (1896: 2). No eran solo las

en el segundo un unicornio conducía a las hermanas del título hasta el eremita que les enseñaba las verdades de la fe cristiana.

6. Probablemente Verlaine le había ayudado a imaginar a ese joven que «viene con la cabellera húmeda todavía porque ha sabido guardar en ella el rocío de la aurora; las mejillas rosadas de besos, porque es el tiempo del Amor» (1938: 80) — «'arrive tout couvert encore de rosée», pudo leer en «Green» (Romances sans paroles) de alguien que además pedía reclinar su cabeza «toute sonore encore» de los últimos besos (Verlaine, 1962: 205)—, lo que refuerza la relación del poeta fallecido con la montaña de las visiones imaginada previamente por Darío. 
exigencias de la tradicional y católica Córdoba las razones que condicionaban la actitud de Rubén, que visitaba esa ciudad para escribir sobre las fiestas de la Virgen del Rosario que entonces se celebraban (Capdevila, 1946: 104). En el homenaje del Ateneo leyó el poema «En elogio del Ilmo. Señor Obispo de Córdoba, fray Mamerto Esquiú, O. M.», que habría de terminar integrado en El canto errante y donde reiteró las sextinas del «Responso». La exaltación del venerable obispo no era necesariamente la «contrapartida» de aquellos versos dedicados a Verlaine, como se ha afirmado en alguna ocasión (Larrea, 1987: 95). La estrofa final del poema aludía ahora a la «verlainiana zampoña» que Rubén tocaba a veces, antes de concluir que esta vez había cantado la «sacra luz» que fray Mamerto Esquiú había significado, y de grabar en su honor «una rosa y una cruz». Darío, quien con la ayuda de Bloy y tras la lectura de Sagesse — «Je ne veux plus aimer que ma mère Marie», declaraba alguno de sus versos (Verlaine, 1962: 266) — se había referido al maestro admirado como «el desventurado, el caído, pero también el armonioso, el místico, el inmenso poeta del Amor inmortal y de la Virgen» (1896: 55), quizá acomodaba también ahora sus inquietudes espirituales y literarias a sus recuerdos de Verlaine.

\section{Bibliografía citada}

BAudelaire, Charles, Les fleurs du mal, ed. Jacques Dupont, Paris, Flanmarion, 1991.

CAPDEVILA, Arturo, Rubén Darío: "Un bardo rei", Buenos Aires, Espasa-Calpe, 1946.

CARLOS, Alberto J., «La cruz en el "Responso a Verlaine"», Hispania, XLVIII, 1965, pp. 226-229.

CavalCa, Fra Domenico, Volgarizzamento delle Vite dei Santi Padri, tomo primo, Milano, per Giovanni Silvestre, 1830.

Darío, Rubén, Los raros, Buenos Aires, Talleres de «La Vasconia», 1896.

- «La vida de Rubén Darío escrita por él mismo para Caras y Caretas», en Caras y Caretas, año XV, número 735, Buenos Aires, 2 de noviembre de 1912, s. p.

- Antología. Poesías de Rubén Darío. Precedida de la historia de mis libros, Madrid, Librería de la Viuda de Gregorio Pueyo, 1916.

— «Frontispicio del libro de Los raros», en Escritos inéditos de Rubén Darío, ed. Erwin K. Mapes, New York, Instituto de las Españas, 1938, pp. 79-80.

— «Discurso en el Ateneo de Córdoba», en Roberto Ibáñez (ed.), Páginas desconocidas de Rubén Darío, Montevideo, Biblioteca de Marcha, 1970, pp. 109-111.

DuFFaU, Eduardo Héctor, «Dónde se publicaron primeramente las piezas que constituyeron Prosas profanas y otros poemas (1896)», Boletín de la Academia Argentina de Letras, XIII, 88, 1958, pp. 265-287. 
García Morales, Alfonso (1997), «El "Frontispicio" de Los raros. Una fuente gráfica desconocida y una explicación», en Cuadernos Hispanoamericanos, 560 (febrero), 1997, pp. 48-62.

LARREA, Juan, Rubén Darío y la nueva cultura americana, ed. Felipe Daniel Obarrio. Valencia, Pre-Textos, 1987.

Marasso, Arturo, Rubén Darío y su creación poética, Buenos Aires, Editorial Kapelusz, 1954 (edición definitiva).

Ovidio NAsón, Publio, Metamorfosis, vol. I (libros I-V), ed. Antonio Ruiz Elvira, Barcelona, Ediciones Alma Mater, 1964.

Plutarco, Pythici Dialogi, De E apud Delphos; De Pythiae oraculis; De defectu oraculorum. Edidit W. Sieveking (Editionem correctiorem curavit Hans Gärtner), Stuttgart / Leipzig, Teubner, 1997.

TRUeblOOD, Alan S., «El "Responso" a Verlaine y la elegía pastoril tradicional», en Carlos H. Magis (ed.), Actas del III Congreso Internacional de Hispanistas (México D. F., 26-31 de agosto de 1968), México, El Colegio de México, 1970, pp. 861-870.

Verlaine, Paul, Euvres poétiques complètes (Texte établi et annoté par Y.-G. Le Dantec. Édition révisée et présentée par Jacques Borel), Paris, Gallimard (Bibliothèque de la Pléiade), 1962.

VIRGILIO, Bucólicas, ed. bilingüe Vicente Cristóbal, Madrid, Ediciones Cátedra, 1996. 